\title{
Evaluation of Needlestick Injuries and Other Exposures to Bloodborne Pathogens Among Officers in a City Police Department
}

\section{Marie A. de Perio, MD}

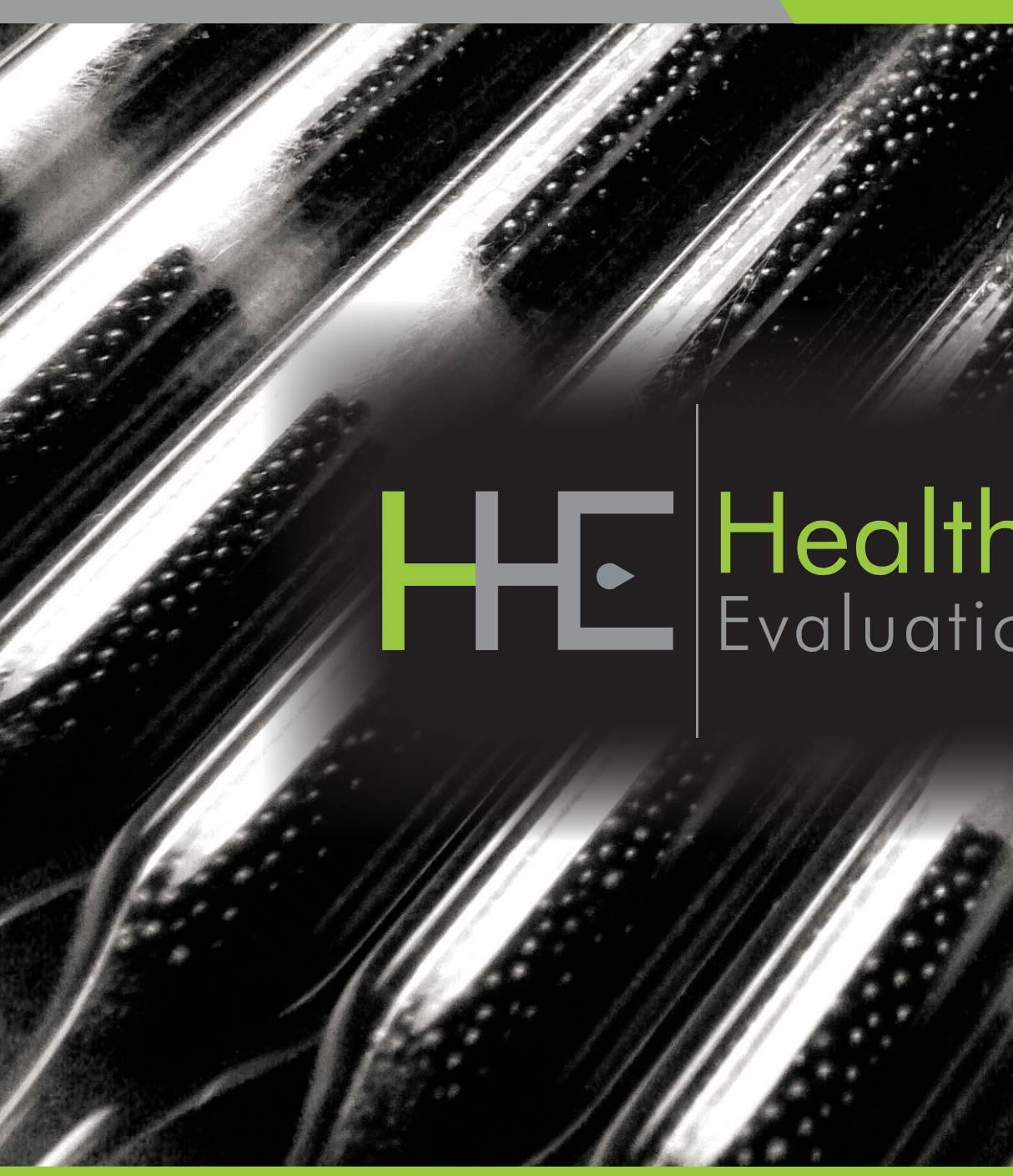

HHE Report No. 2016-0121-3284

July 2017

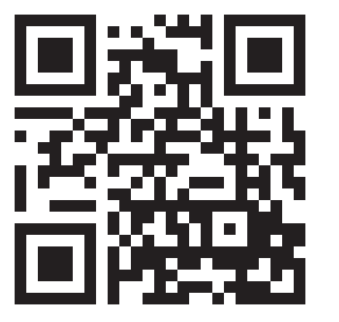

U.S. Department of Health and Human Services Centers for Disease Control and Prevention National Institute for Occupational Safety and Health
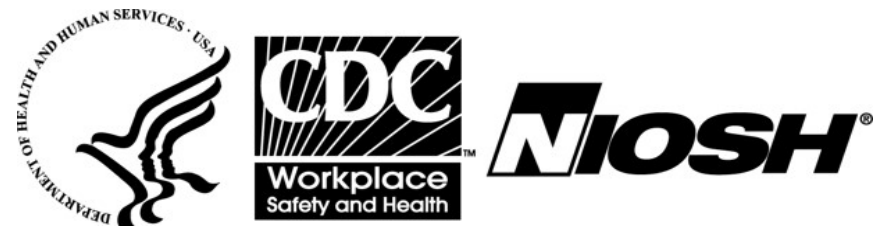


\section{Contents}

Highlights.

Abbreviations ...................................... iii

Introduction ................................... 1

Methods ............................................. 2

Results ................................................. 2

Discussion ........................................... 7

Conclusions.......................................... 9

Recommendations............................ 9

Appendix A ........................................ 12

References ........................................ 13

Acknowledgements............................ 17

The employer is required to post a copy of this report for 30 days at or near the workplace(s) of affected employees. The employer must take steps to ensure that the posted report is not altered, defaced, or covered by other material.

The cover photo is a close-up image of sorbent tubes, which are used by the HHE Program to measure airborne exposures. This photo is an artistic representation that may not be related to this Health Hazard Evaluation. Photo by NIOSH. 


\section{Highlights of this Evaluation}

The Health Hazard Evaluation Program received a request from employer representatives at the risk management office in a city in Ohio. The request concerned needlestick injuries and other potential exposures to bloodborne pathogens among police officers in that city.

\section{What We Did}

- We reviewed the city's and police department's policies regarding bloodborne pathogens and exposures to blood or other potentially infectious materials.

- We reviewed the police department's needlestick injury and exposure incident reports from 2011-2016 and then analyzed the information in them.

\section{What We Found}

- The city's bloodborne pathogens exposure control plan was comprehensive, but the police department had not yet adopted the plan.

- Thirteen needlestick injuries were reported across a 6-year period in a force of about 1,000 officers.

- Nine of 11 source persons tested were found to have hepatitis C. None were found to have hepatitis B or HIV.

- Most needlestick injuries occurred during pat down searches of a suspect and during searches of a suspect's property or vehicle.

- Thirty-seven additional potential bloodborne pathogens exposure incidents were reported, involving mostly spitting incidents, human bites, and contact with blood other than from needlesticks.

\section{What the Employer Can Do}

We reviewed records of needlestick injuries and other potential bloodborne pathogens exposure incidents among police officers in a city department. We found 13 needlestick injuries and 37 additional exposure incidents across a 6-year period. Nine of 11 source persons tested for needlestick injuries were found to have hepatitis $C$. The city had a comprehensive bloodborne pathogens exposure control plan, but the police department had not yet adopted it. We recommended improvements to engineering, administrative, and personal protective equipment controls.

- Adopt the city's comprehensive bloodborne pathogens exposure control plan.

- Ensure that the sharps containers for evidence collection are puncture resistant, leakproof, and labeled or color-coded.

- Make sure that the needlestick injury and other exposure incident reports have complete information.

- Continue to train police officers on safe searching techniques. 


\section{What Employees Can Do}

- Transfer used needles promptly in appropriate sharps containers.

- Promptly report all needlestick injuries and other potential exposure incidents. 


\section{Abbreviations}

CFR Code of Federal Regulations

HIV Human immunodeficiency virus

NAICS North American Industry Classification System

NIOSH National Institute for Occupational Safety and Health

OSHA Occupational Safety and Health Administration 
This page left intentionally blank 


\section{Introduction}

The Health Hazard Evaluation Program received a request from employer representatives at the risk management office in a city in Ohio. The request concerned needlestick injuries and other potential exposures to bloodborne pathogens among police officers in that city.

\section{Police Department}

At the time of the evaluation, the city's police department was the primary law enforcement agency for the city and provided police services to residents in five districts. The department had approximately 1,000 sworn officers and 125 civilian employees. Law enforcement operations were divided among three bureaus: patrol, investigations, and support. Historically, the department received 160,000-210,000 reactive calls for service a year, in which a 911 call is received and results in a call for service. Police officers assigned to the districts for uniform patrol activity worked on one of three fixed shifts. The first shift had starting times of 0600 and 0700 hours. The second shift had starting times of 1300, 1400, or 1500 hours, and the third shift had start times of 2200 or 2300 hours depending on the service demands of the individual district. The third shift was supplemented by a late-power shift with starting times of 1900 and 2100 hours.

\section{Needlestick Injuries and Other Sources of Exposure to Bloodborne Pathogens}

Police officers are at risk of bloodborne diseases through needlestick injuries and other exposure incidents because of the nature of their work [Lorentz et al. 2000; Pagane et al. 1996]. The bloodborne pathogens of most concern include hepatitis $\mathrm{B}$ virus, hepatitis $\mathrm{C}$ virus, and human immunodeficiency virus (HIV). More information on these pathogens can be found in Appendix A. No studies have addressed the risk of infection with these viruses among police officers.

In 1991, the Occupational Safety and Health Administration (OSHA) issued its bloodborne pathogens standard, requiring employers to maintain a written exposure control plan and to adopt engineering and work practice controls that would eliminate or minimize employee exposure from hazards associated with bloodborne pathogens [29 CFR 1910.1030]. The standard was most recently revised in 2001. This revision added new requirements for employers, including additions to the exposure control plan and keeping a sharps injury $\log$. It specifies in detail the engineering controls, such as safer medical devices, that must be used to reduce or eliminate worker exposure [29 CFR 1910.1030]. These measures are required for private industry employees and only for public employees in states operating OSHA-approved state plans. Ohio does not operate a state OSHA plan; therefore, the police department is not required to implement these requirements. However, we recommend voluntary compliance to improve the health and safety of police officers. 


\section{Methods}

The objectives of our evaluation were to determine the incidence of needlestick injuries and other potential exposures to bloodborne pathogens among police officers from 2011-2016 and to assess the controls in place to reduce the occurrence of these exposures.

Our evaluation included the following activities: (1) a review of the city's written bloodborne pathogens program and the police department's exposure protocol, and (2) an analysis of the department's needlestick injury and other bloodborne pathogens exposure incidents reports.

\section{Review of Department's Written Policies and Procedures}

We reviewed (1) the city's bloodborne pathogens exposure control plan, (2) the police department's exposure protocol, which is part of the police department procedure manual, and (3) the police department's investigation of employee injury form. This is a general form for any type of injury affecting an officer including needlestick injuries and other exposure incidents. We looked to see if these written documents met the requirements set forth by the OSHA bloodborne pathogens standard [29 CFR 1910.1030].

\section{Analysis of the Department's Needlestick Injury and Exposure Incident Reports}

We obtained an electronic spreadsheet containing data from reports on all needlestick injuries and other potential bloodborne pathogens exposure incidents from January 1, 2011, through December 31, 2016. These reports were extracted by the representative from the city's risk management office from the city's human resource information system, the centralized database maintained by the city's employee safety department. Using the information in the spreadsheet given to us, we characterized the circumstances surrounding the reported injuries and exposures. We calculated the annual incidence of needlestick injuries using two methods: (1) by dividing the total number of needlestick injuries reported during a given year by the total number of police officers employed by the city during that same year, and (2) by dividing the total number of needlestick injuries reported during a given year by the total number of reactive calls for service during that same year. We ran a Poisson regression model to determine the trend in the annual incidence over time using SAS 9.4. We considered a $P$ value $<0.05$ to indicate statistical significance.

\section{Results}

\section{Review of City's and Department's Written Policies and Procedures}

At the time of our evaluation, the city and the police department defined a bloodborne pathogens exposure as a percutaneous injury (i.e., needlestick) or contact of mucous membrane or nonintact skin with blood or potentially infectious material. The city's bloodborne pathogens exposure control plan, released in March 2016, was comprehensive 
and contained all of the elements in the OSHA bloodborne pathogens standard [29 CFR 1910.1030]. These elements include an exposure determination, methods of compliance, hepatitis $B$ vaccination, postexposure evaluation and follow-up, communication of hazards to employees, and recordkeeping. The city's control plan states that hepatitis B vaccination is made available at no cost to an employee within 10 days of being assigned to a position with reasonably anticipated occupational exposure to blood or other potentially infectious materials. Employees who decline hepatitis B vaccination must sign a waiver. At the time of our evaluation, the police department had not yet adopted the city's bloodborne pathogens exposure control plan.

According to the police department procedure manual, all new police officers are given a 2-hour training session on bloodborne pathogens during academy training. However, subsequent annual training is reportedly not offered for officers. Nitrile gloves are reportedly available in the district offices to police officers for their use, but officers are not officially issued a supply.

According to the police department's exposure protocol, which is part of the police department procedure manual, affected employees are instructed to immediately report the incident to a supervisor and then to the employee health service office. The supervisor then makes a determination, with assistance from the bloodborne pathogen injury telephone line at the designated medical center, if an occupational exposure has occurred. If such an exposure is determined, the affected officer and source person are sent to the medical center for testing. At the time of our evaluation, the police department's exposure protocol was electronically accessible to all officers through the department's intranet. Paper copies were reportedly available in each of the district offices.

The police department's investigation of employee injury form encompasses all potential types of injuries and exposure incidents affecting officers. It is not specific for needlestick injuries. However, the form does have a field for the address of occurrence and an explanation of how the incident occurred, which is consistent with the OSHA bloodborne pathogens standard [29 CFR 1910.1030]. It does not have a specific field for the type and brand of device involved in the incident, but this information is collected under the category of needlestick details.

At the time of our evaluation, the police department used containers made of heavy-duty fiberboard with a metal screw-on lid (Figure 1). The containers were used to temporarily store needles or other sharps collected in the field. According to the OSHA bloodborne pathogens standard, sharps containers shall be puncture resistant, labeled or color-coded in accordance with the standard, and leakproof on the sides and bottom [29 CFR 1910.1030]. The containers used by the police department do not meet these criteria. 


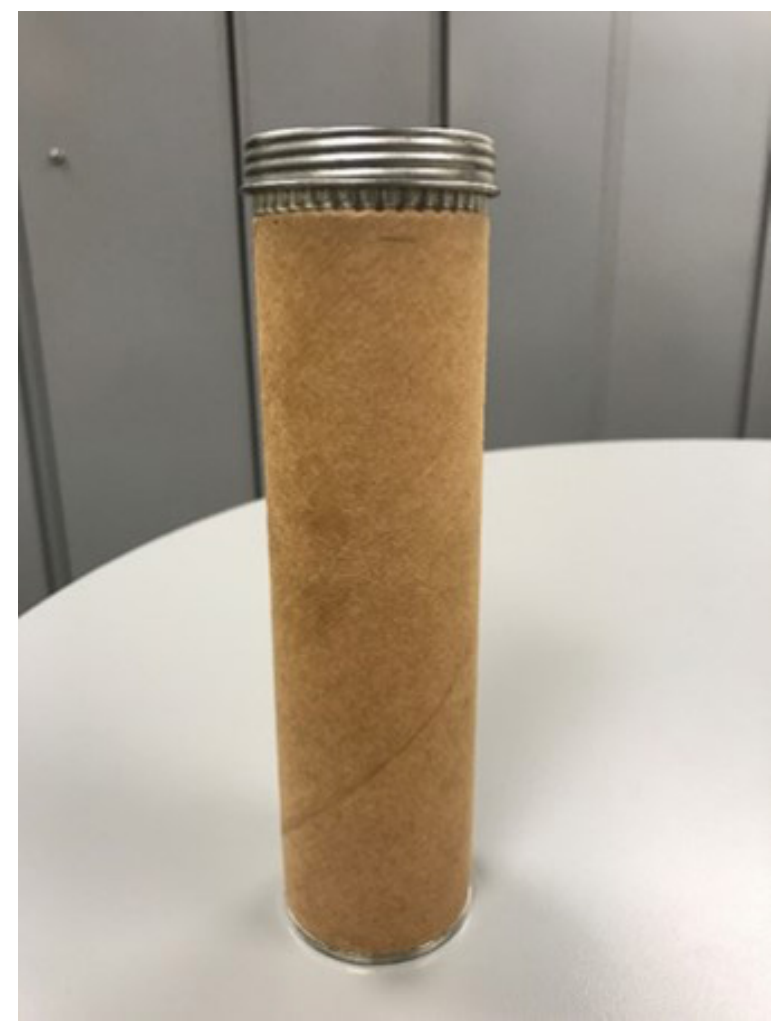

Figure 1. The container used by the police department for storing evidence involving needles and other sharps. Photo by National Institute for Occupational Safety and Health (NIOSH).

\section{Analysis of the Department's Needlestick Injury Reports}

A total of 13 needlestick injuries were recorded in the department's database from January 1, 2011-December 31, 2016. The 13 needlestick injuries were experienced by 13 officers working in the criminal investigation section $(n=1)$ and all police districts except for District 2: District $1(n=5)$, District $3(n=4)$, District $4(n=1)$, District $5(n=2)$.

In total, 4 needlestick injuries occurred during first shift, 5 occurred during second shift, and 1 occurred during third shift. Two injuries occurred between 1400 and 1430, which could have been first or second shift. One injury did not have a time recorded. No seasonality pattern was detected as the 13 injuries occurred during 9 different months, all but May, July, and August.

Of the 13 needlestick injuries, 7 involved the hand, 5 involved a finger, and 1 involved the abdomen. The median age of the 13 officers sustaining needlestick injuries was 40 years (range: $28-50$ years). The median length of service was 9 years (range: 5-24 years). Information about the brand of the needle and protective mechanisms of the device was unknown for 12 of the injuries. One injury involved a lancet needle used for checking blood glucose. Gloves were reportedly worn by officers in 7 of the incidents. Of these, latex gloves were reportedly used in 4 incidents, "rubber" gloves were used in 1 incident, and the type of gloves used was not recorded in 2 incidents. Gloves were reported not to be worn in 2 incidents, and it was unknown if officers were wearing gloves for 4 instances. Two injuries resulted from officers not immediately securing identified syringes. Explanations of how the injuries occurred are displayed in Table 1. 
Table 1. Explanation of how the needlestick injuries occurred as described in the department's needlestick injury reports

\begin{tabular}{lc}
\hline Explanation & $\begin{array}{c}\text { No. injuries } \\
\mathrm{n}=13\end{array}$ \\
\hline During pat down of a suspect & 4 \\
During search of suspect's purse & 4 \\
During search of suspect's vehicle & 3 \\
Sharp left by officer in inappropriate place & 1 \\
During inspection of capped needle & 1 \\
\hline
\end{tabular}

Of the 13 affected police officers, 12 had medical evaluation and treatment at a university medical center following the incident; the remaining officer was treated at the city's employee health service. The source person was also evaluated at the university medical center in 8 incidents and at the local jail in 2 instances. The source person's treatment facility was not listed for 3 incidents, and the source person results were not recorded for 2 of these incidents. It is unclear if these 2 source persons were evaluated at all. Nine (82\%) of 11 source persons with test results were found to have hepatitis C. None of the 11 source persons with test results were found to have HIV or hepatitis B. We were unable to obtain test results for the injured police officers but were informed that none of the incidents led to transmission of hepatitis B, hepatitis C, or HIV.

The annual incidence of needlestick injuries ranged from $0-5.07$ per 1,000 police officers and from $0-2.45$ per 10,000 reactive calls for service (Table 2 and Figure 2). The year 2012 had the highest incidence at 5.07 needlestick injuries per 1,000 police officers and 2.45 needlestick injuries per 10,000 reactive calls for service. The year 2016 saw no needlestick injuries among police officers. We did not identify a significant trend in annual incidence of needlestick injuries per 1,000 police officers $(P=0.22)$ or per 10,000 reactive calls for service $(P=0.34)$.

Table 2. Annual numbers of needlestick injuries, police officers, and reactive calls for service

\begin{tabular}{cccccc}
\hline Year & $\begin{array}{c}\text { No. } \\
\text { needlestick } \\
\text { injuries }\end{array}$ & $\begin{array}{c}\text { No. police } \\
\text { officers }\end{array}$ & $\begin{array}{c}\text { Annual incidence } \\
\text { per } 1,000 \\
\text { police officers }\end{array}$ & $\begin{array}{c}\text { No. reactive } \\
\text { calls for service }\end{array}$ & $\begin{array}{c}\text { Annual incidence } \\
\text { per 10,000 reactive } \\
\text { calls for service }\end{array}$ \\
\hline 2011 & 1 & 1,031 & 0.97 & 204,085 & 0.05 \\
2012 & 5 & 986 & 5.07 & 204,427 & 2.45 \\
2013 & 3 & 959 & 3.13 & 206,425 & 1.45 \\
2014 & 2 & 1,012 & 1.98 & 201,240 & 0.99 \\
2015 & 2 & 1,010 & 1.98 & 192,035 & 1.04 \\
2016 & 0 & 1,043 & 0 & 187,918 & 0 \\
\hline
\end{tabular}




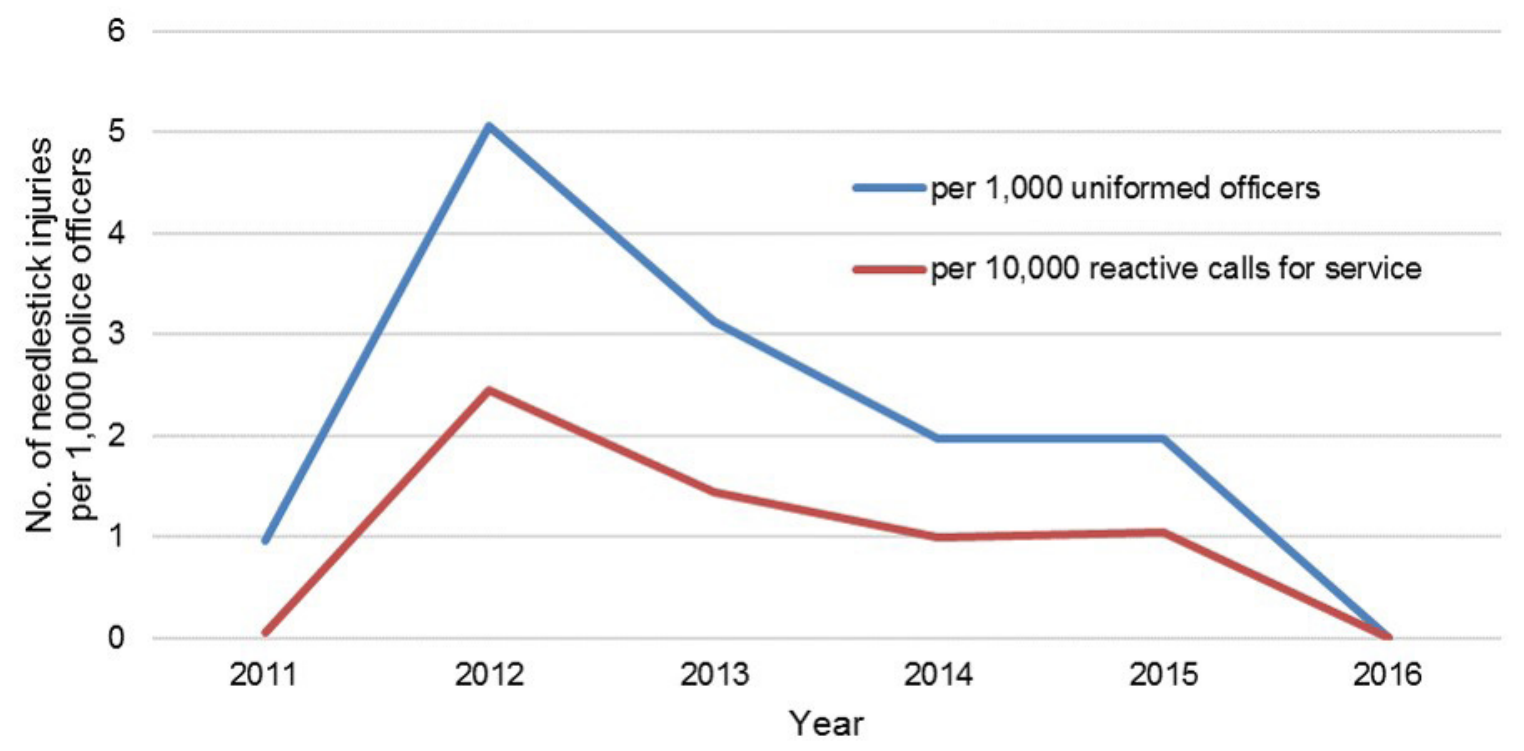

Figure 2. Annual incidence of needlestick injuries

Thirty-seven additional exposure (non-needlestick) incidents were reported from January 1, 2011-December 31, 2016. Explanations of how the exposure incidents occurred are displayed in Table 3. Based on the information in the database, only some of these incidents be classified as a true potential risk for exposure to bloodborne pathogens. These incidents include spit in the eyes or mouth, blood contact with non-intact skin, and blood contact with mucous membranes.

The 37 exposure incidents occurred in all five police districts and the central business district as follows: District $1(n=9)$, District $2(n=3)$, District $3(n=10)$, District $4(n=7)$, District $5(\mathrm{n}=7)$, central business district $(\mathrm{n}=1)$. In total, 2 incidents occurred during first shift, 9 incidents occurred during second shift, and 14 incidents occurred during third shift. Six incidents occurred between 1300 and 1430 hours, which could have been first or second shift. Four incidents occurred between 2000 and 2100 hours, which could have been second or third shift. One incident occurred between 0600 and 0700 hours, which could have been third or first shifts. One incident was missing the time. No seasonality pattern was detected as the 37 exposure incidents occurred during all 12 months. The median age of the 31 officers reported to have exposure incidents was 37 years (range: 24-52 years). The median length of service was 10 years (range: 1 year-25 years).

Of the 37 police officers with reported exposure incidents, 26 had medical evaluation and treatment at a university medical center or the city's employee health service, seven did not undergo treatment, and four had an unknown status. The source person was also evaluated at a local hospital in 19 incidents and at the local jail in 3 incidents. The evaluation location was not listed for 8 incidents, but five of these source persons had a "verbal" report of test results back to the city's employee health service. Seven source persons did not receive any medical evaluation or treatment. 
Table 3. Explanation of how the other exposure incidents occurred as described in the department's exposure incident reports

\begin{tabular}{|c|c|}
\hline Explanation & $\begin{array}{l}\text { No. incidents } \\
n=37^{*}\end{array}$ \\
\hline Spit in the eyes or mouth $\uparrow$ & 9 \\
\hline Spit in the face $†$ & 6 \\
\hline Human bite†‡ & 6 \\
\hline Blood contact with non-intact skin§ & 5 \\
\hline Blood contact with mucous membrane§ & 1 \\
\hline Blood contact with skin (unknown if intact) $\dagger$ & 7 \\
\hline Other†ा & 4 \\
\hline \multicolumn{2}{|c|}{$\begin{array}{l}\text { *One incident involved a blood exposure and spitting on } \\
\text { the face. }\end{array}$} \\
\hline \multicolumn{2}{|c|}{$\begin{array}{l}\text { †There is insufficient information to determine if these } \\
\text { incidents would be considered at risk for exposure to } \\
\text { bloodborne pathogens. }\end{array}$} \\
\hline \multicolumn{2}{|c|}{$\begin{array}{l}\text { ‡Three bites were reported to have broken the officer's skin, } \\
\text { one reportedly did not break skin, and two incidents did not } \\
\text { report breakage of skin. }\end{array}$} \\
\hline \multicolumn{2}{|c|}{$\begin{array}{l}\S \text { These types of exposures would generally be considered at } \\
\text { risk for exposure to bloodborne pathogens. }\end{array}$} \\
\hline \multicolumn{2}{|c|}{$\begin{array}{l}\text { TOther exposure incidents include cough into the face, } \\
\text { abrasion, puncture wound from dental retainer, and } \\
\text { unprotected mouth-to-mouth resuscitation during } \\
\text { cardiopulmonary resuscitation. }\end{array}$} \\
\hline
\end{tabular}

In six incidents, neither the source person nor the police officer underwent medical evaluation. Based on the information provided in the report, five of these incidents would generally not be classified as at risk of exposure to bloodborne pathogens. Three incidents involved spitting incidents, one bite that did not break the skin, and one involved unprotected mouth-to-mouth resuscitation during cardiopulmonary resuscitation. Saliva is not typically categorized as a potentially infectious material unless it contains visible blood or is from a dental procedure [29 CFR 1910.1030].

Of the 22 source persons who had blood drawn in a followup evaluation, four (18\%) were found to have hepatitis $\mathrm{C}$ infection, two (9\%) were found to have HIV infection, and one (5\%) was found to have both HIV and hepatitis $\mathrm{C}$ infections. Results were reported as negative for 15 source persons. No source persons were found to have hepatitis B. We were also unable to obtain test results for the police officers involved but were informed that none of the incidents led to transmission of hepatitis B, hepatitis C, or HIV.

\section{Discussion}

We found 13 needlestick injuries and 37 other potential bloodborne pathogens exposure incidents among police officers in this police department. Few studies have focused on needlestick injuries and other potential bloodborne pathogens exposures among law enforcement personnel, and the differences in definitions across the studies make comparisons 
difficult. However, the annual incidence of needlestick injuries we found (0-5.07 per 1,000 police officers) appears to be similar to those in other studies. A retrospective study of police and corrections officers presenting to emergency departments in Rhode Island found an average annual incidence of 0.78 percutaneous or blood to mucous membrane exposures per 1,000 police and corrections personnel [Merchant et al. 2008]. Another study looking at surveillance records from the New York City police department found the rate of needlesticks to be 4.8 needlestick injuries per 10,000 police officers (or 0.48 needlestick injuries per 1,000 police officers) per year. The authors found that younger age (20-29 years) and having 4-10 years of service were associated with a higher risk of transcutaneous exposures (needlestick injuries and human bites) [Pagane et al. 1996]. More recent survey studies in North Carolina and Baltimore, Maryland have documented that $3.8 \%-8 \%$ of police officers reported ever having a needlestick injury and a rate of 36-58 needlestick injuries per 10,000 officer-years (or 3.6-5.8 needlestick injuries per 1,000 officer-years) [Cepeda et al. 2017; Davis et al. 2014].

Sonder et al. identified 112 exposures with risk for viral transmission in Amsterdam, the Netherlands over a 4-year period. Of these, almost half were exposed through human bites; $10 \%$ were needlestick injuries [Sonder et al. 2005]. A review of case reports of blood and body fluid exposures by police officers in Scotland from August 2007-July 2008 found 105 incidents reported. Of these, the most common types were spits $(27 \%)$, bites $(26 \%)$, and splashes $(23 \%)$. Five needlestick injuries were reported [Dunleavy et al. 2010]. Similar to these studies, we found that most exposure incidents consisted of spitting incidents, human bites, and contact with blood other than from a needlestick $(n=33)$. As noted above, saliva is not typically categorized as a potentially infectious material unless it contains visible blood or is from a dental procedure [29 CFR 1910.1030]. For human bites, clinical evaluation must include the possibility that both the person bitten and the person who inflicted the bite were exposed to bloodborne pathogens. Transmission of HIV by this route has been reported in rare instances, but not after an occupational exposure [Kuhar et al. 2013].

Among the reported needlestick injuries at another metropolitan department, $42 \%$ of respondents reported that the incidents occurred during second shift or evening. The most common circumstances were pat down searches (36\%), searches incident to arrest $(25 \%)$, property searches $(10 \%)$, and vehicle searches (10\%) [Lorentz et al. 2000]. Our evaluation revealed 11 of 13 needlestick injuries occurred during either first or second shifts, while 27 of 31 other exposures occurred during either second or third shifts. The reasons for this difference are not known. In this police department, needlestick injuries most commonly occurred during pat down searches of a suspect and during searches of a suspect's property or vehicle, which is similar to previous findings [Lorentz et al. 2000]. These appear to be high risk activities because of their unpredictable nature. Regular training on safe searching techniques and safe handling of needles may further minimize risks of needlestick injuries. Police officers should not reach into any areas that they cannot see without first looking. Syringe service programs, such as the one started in the city in 2014, remove potentially contaminated syringes from the community and may reduce the risk of needlesticks to the public and first responders [Des Jarlais et al. 2015; Groseclose et al. 1995].

Despite the relatively low number of needlestick injuries and other potential bloodborne pathogens exposures in this police department, it is important for the police department to have a bloodborne pathogens exposure control plan. In this evaluation, $82 \%$ of source persons for 
needlestick injuries with test results and $23 \%$ of source persons for other exposures with test results were found to have hepatitis $\mathrm{C}$ infection while $14 \%$ of source persons for other exposures with test results were found to have HIV infection. The police department had not yet adopted the city's comprehensive bloodborne pathogens exposure control plan, which contained all of the required elements of the OSHA bloodborne pathogens standard [29 CFR 1910.1030]. Although the police department had an exposure protocol in its procedure manual, this protocol did not cover all the elements needed for a comprehensive bloodborne pathogens exposure control plan.

Our evaluation was subject to some limitations. First, the incidence of needlestick injuries and other exposure incidents reported here may be an underestimation of the actual incidence of these injuries among officers. Previous studies have shown that underreporting of needlestick injuries and exposure incidents in police officers occurs. Only $39 \%$ of police officers in San Diego, California reported seeking medical attention for needlestick injuries while $43 \%$ of police officers in Denver, Colorado stated they reported their exposure to blood or saliva [Hoffman et al. 1994; Lorentz et al. 2000]. Second, we did not have sufficient information to determine if multiple reported non-needlestick incidents would be considered at risk for exposure to bloodborne pathogens. Third, we were unable to obtain test results and other records for the affected police officers after the exposure incidents so we are unable to comment on whether or not police officers underwent the appropriate evaluation and testing. However, we were informed by representatives of the risk management office that none of the incidents led to transmission of hepatitis B, hepatitis C, or HIV.

\section{Conclusions}

Police officers in this department are at risk for needlestick injuries and other potential exposures to bloodborne pathogens. In our retrospective review of reports of exposure incidents, we found 13 needlestick injuries and 37 other potential bloodborne pathogens exposures over a 6-year period. Nine of 11 source persons with documented test results after a needlestick injury were found to have hepatitis $\mathrm{C}$. Needlestick injuries most commonly occurred during pat-down searches of a suspect and during search of a suspect's property or vehicle. The annual incidence of needlestick injuries ranged from 0-5.07 per 1,000 police officers and from 0-2.45 per 10,000 reactive calls for service. Most exposure incidents consisted of spitting incidents, human bites, and contact with blood other than from a needlestick. The police department had not yet adopted the city's comprehensive bloodborne pathogens exposure control plan, which contained all of the required elements of the OSHA bloodborne pathogens standard.

\section{Recommendations}

On the basis of our findings, we recommend the actions listed below. We encourage the city and the police department to use a labor-management health and safety committee or working group to discuss our recommendations and develop an action plan. Those involved in the work can best set priorities and assess the feasibility of our recommendations for the specific situation at the police department.

Our recommendations are based on an approach known as the hierarchy of controls. This approach groups actions by their likely effectiveness in reducing or removing hazards. In 
most cases, the preferred approach is to eliminate hazardous materials or processes and install engineering controls to reduce exposure or shield employees. Until such controls are in place, or if they are not effective or feasible, administrative measures and personal protective equipment may be needed.

\section{Engineering Controls}

Engineering controls reduce employees' exposures by removing the hazard from the process or by placing a barrier between the hazard and the employee. Engineering controls protect employees effectively without placing primary responsibility of implementation on the employee.

1. Ensure that the containers used to temporarily store needles or other sharps collected as evidence in the field are puncture resistant, leakproof, and labeled or color-coded.

\section{Administrative Controls}

The term administrative controls refers to employer-dictated work practices and policies to reduce or prevent hazardous exposures. Their effectiveness depends on employer commitment and employee acceptance. Regular monitoring and reinforcement are necessary to ensure that policies and procedures are followed consistently.

1. Fulfill the requirements of the OSHA bloodborne pathogens standard [29 CFR 1910.1030].

a. Adopt the city's comprehensive bloodborne pathogens exposure control plan.

b. Provide all police officers with annual training on bloodborne pathogens, methods used to control occupational exposures, hepatitis B vaccine, and medical evaluation and post-exposure follow up procedures.

2. Ensure that each needlestick injury report contains all of the information required by the OSHA bloodborne pathogens standard [29 CFR 1910.1030]. This information includes the work area where the exposure occurred and an explanation of how the incident occurred. Check each submitted report for completeness, and address missing or incomplete responses.

3. Instruct police officers to transfer needles promptly in appropriate containers. Officers should never attempt to recap needles.

4. Encourage all police officers to report all needlestick injuries and other exposure incidents immediately. Emphasize the importance of timely medical evaluation and treatment.

5. Continue to train police officers on safe searching techniques. Police officers should not reach into any areas that they cannot see. They should first look into the area to check for anything hazardous.

\section{Personal Protective Equipment}

Personal protective equipment is the least effective means for controlling hazardous exposures. Proper use of personal protective equipment requires a comprehensive program and a high 
level of employee involvement and commitment. The right personal protective equipment must be chosen for each hazard. Supporting programs such as training, change-out schedules, and medical assessment may be needed. Personal protective equipment should not be the sole method for controlling hazardous exposures. Rather, personal protective equipment should be used until effective engineering and administrative controls are in place.

1. Continue to provide police officers with nitrile gloves to prevent dermal exposure to blood and other potentially infectious materials. Latex gloves may lead to the development of allergies and skin rashes and should not be used.

2. Consider providing officers with cut-resistant gloves for their use when they are performing searches and pat-downs.

3. Weigh the risks and benefits of providing police officers with a face shield or safety glasses, which may protect them from splashes and spitting incidents. 


\section{Appendix A: Bloodborne Pathogens}

\section{Human Immunodeficiency Virus}

HIV, also known as the human immunodeficiency virus, is the virus that can lead to acquired immune deficiency syndrome, or AIDS. HIV attacks the body's immune system by destroying specific blood cells, called CD4+ T cells, which are crucial to helping the body fight diseases. In 2015, 39,513 people were diagnosed with HIV infection in the United States. More than 1.2 million in the United States are living with HIV, and 1 in 8 of them do not know it [Centers for Disease Control and Prevention 2016a].

As of December 13, 2013, 58 confirmed occupational transmissions of HIV and 150 possible transmissions had been reported in the United States. Of these, only one confirmed case had been reported since 1999 [Centers for Disease Control and Prevention 2016b]. The average risk for HIV transmission after a percutaneous exposure to HIV-infected blood has been estimated to be approximately 0.3\% [Bell 1997; Gerberding 1994; Ippolito et al. 1999]. Risk of exposure due to splashes with body fluids is thought to be near zero even if the fluids are overtly bloody. Fluid splashes to intact skin or mucous membranes are considered to be extremely low risk of HIV transmission, whether or not blood is involved [Centers for Disease Control and Prevention 2016b].

\section{Hepatitis B}

Hepatitis B is a contagious liver disease that results from infection with the hepatitis B virus. It can range in severity from a mild illness lasting a few weeks to a serious, lifelong illness. Hepatitis B virus is transmitted through percutaneous, mucosal, or nonintact skin exposure to infectious blood or body fluids. Effective hepatitis B vaccines have been available in the United States since 1981, and since then, the incidence of acute hepatitis B has declined. The estimated incidence of hepatitis B infection was 19,200 in 2014, but an estimated 850,0002.2 million persons are living with chronic hepatitis B infection [Centers for Disease Control and Prevention 2016c]. The rate of hepatitis B transmission to susceptible (or nonimmunized) healthcare workers ranges from 6\%-30\% after a single needlestick exposure from a hepatitis B infected patient [Centers for Disease Control and Prevention 1997].

\section{Hepatitis C}

Hepatitis $\mathrm{C}$ is a contagious liver disease that results from infection with the hepatitis $\mathrm{C}$ virus. It can range in severity from a mild illness lasting a few weeks to a serious, lifelong illness. It more commonly causes chronic infection than hepatitis B. Hepatitis $\mathrm{C}$ virus is transmitted primarily through repeated percutaneous exposure to infectious blood such as through injection drug use; receipt of donated blood, blood products, or organs; needlestick injuries; and birth to a hepatitis C-infected mother. An estimated 2.7-3.9 million persons are chronically infected with hepatitis C [Armstrong et al. 2006; Centers for Disease Control and Prevention 2016c]. It was estimated that 30,500 acute hepatitis $C$ cases occurred in 2014 [Centers for Disease Control and Prevention 2016c]. The average rate of hepatitis $\mathrm{C}$ transmission averages $1.8 \%$ for healthcare workers exposed to hepatitis $\mathrm{C}$ through a needlestick or percutaneous injury [Alter 1997; Centers for Disease Control and Prevention 1998]. 


\section{References}

Alter MJ [1997]. The epidemiology of acute and chronic hepatitis C. Clin Liver Dis 1(3):559-569.

Armstrong GL, Wasley AM, Simard EP, McQuillan GM, Kuhnert WL, Alter MJ [2006]. The prevalence of hepatitis C virus infection in the United States, 1999 through 2002. Ann Intern Med 144(10):705-714, http://dx.doi.org/10.7326/0003-4819-144-10-200605160-00004.

Bell DM [1997]. Occupational risk of human immunodeficiency virus infection in healthcare workers: an overview. Am J Med 102(3B):294S-300S, https://doi.org/10.1093/oxfordjournals.aje.a117097.

Centers for Disease Control and Prevention [1997]. Immunization of health care workers: recommendations of the Advisory Committee on Immunization Practices (ACIP) and the Hospital Infection Control Practices Advisory Committee (HICPAC). MMWR 46(RR-18):1-42.

Centers for Disease Control and Prevention [1998]. Recommendations for prevention and control of hepatitis $\mathrm{C}$ virus (HCV) infection and $\mathrm{HCV}$-related chronic disease. MMWR 47(RR-19):1-39.

Centers for Disease Control and Prevention [2016a]. HIV in the United States: at a glance, https://www.cdc.gov/hiv/statistics/overview/ataglance.html.

Centers for Disease Control and Prevention [2016b]. Occupational HIV transmission and prevention among health care workers, https://www.cdc.gov/hiv/workplace/healthcareworkers.html.

Centers for Disease Control and Prevention [2016c]. Viral hepatitis - statistics and surveillance, https://www.cdc.gov/hepatitis/statistics/index.htm.

Cepeda JA, Beletsky L, Sawyer A, Serio-Chapman C, Smelyanskaya M, Han J, Robinowitz N, Sherman SG [2017]. Occupational safety in the age of the opioid crisis: needle stick injury among Baltimore police. J Urban Health 94(1):100-103, https://doi.org/10.1007/s11524-016-0115-0.

CFR. Code of Federal Regulations. Washington, DC: U.S. Government Printing Office, Office of the Federal Register.

Davis CS, Johnston J, de Saxe Zerden L, Clark K, Castillo T, Childs R [2014]. Attitudes of North Carolina law enforcement officers toward syringe decriminalization. Drug Alcohol Depend 144:265-269, https://doi.org/10.1016/j.drugalcdep.2014.08.007.

Des Jarlais DC, Nugent A, Solberg A, Feelemyer J, Mermin J, Holtzman D [2015]. Syringe service programs for persons who inject drugs in urban, suburban, and rural areas - United States, 2013. MMWR 64(48):1337-1341, https://doi.org/10.15585/mmwr.mm6448a3.

Dunleavy K, Taylor A, Gow J, Cullen B, Roy K [2010]. Management of blood and body fluid exposures in police service staff. Occup Med (Lond) 60(7):540-545, https://doi.org/10.1093/occmed/kqq111. 
Gerberding JL [1994]. Incidence and prevalence of human immunodeficiency virus, hepatitis $\mathrm{B}$ virus, hepatitis $\mathrm{C}$ virus, and cytomegalovirus among health care personnel at risk for blood exposure: final report from a longitudinal study. J Infect Dis 170(6):1410-1417, https://doi.org/10.1093/infdis/170.6.1410.

Groseclose SL, Weinstein B, Jones TS, Valleroy LA, Fehrs LJ, Kassler WJ [1995]. Impact of increased legal access to needles and syringes on practices of injecting-drug users and police officers--Connecticut, 1992-1993. J Acquir Immune Defic Syndr Hum Retrovirol 10(1):82-89.

Hoffman RE, Henderson N, O'Keefe K, Wood RC [1994]. Occupational exposure to human immunodeficiency virus (HIV)-infected blood in Denver, Colorado, police officers. Am J Epidemiol 139(9):910-917, https://doi.org/10.1093/oxfordjournals.aje.a117097.

Ippolito G, Puro V, Heptonstall J, Jagger J, De Carli G, Petrosillo N [1999]. Occupational human immunodeficiency virus infection in health care workers: worldwide cases through September 1997. Clin Infect Dis 28(2):365-383, https://doi.org/10.1086/515101.

Kuhar DT, Henderson DK, Struble KA, Heneine W, Thomas V, Cheever LW, Gomaa A, Panlilio AL; US Public Health Service Working Group [2013]. Updated US Public Health Service guidelines for the management of occupational exposures to human immunodeficiency virus and recommendations for postexposure prophylaxis. Infect Control Hosp Epidemiol 34(9):875-892, http://doi.org/10.1086/672271.

Lorentz J, Hill L, Samimi B [2000]. Occupational needlestick injuries in a metropolitan police force. Am J Prev Med 18(2):146-150, http://doi.org/10.1016/S0749-3797(99)00137-3.

Merchant RC, Nettleton JE, Mayer KH, Becker BM [2008]. HIV post-exposure prophylaxis among police and corrections officers. Occup Med (Lond) 58(7):502-595, https://doi.org/10.1093/occmed/kqn083.

Pagane J, Chanmugam, Kirsch T, Kelen GD [1996]. New York City police officers incidence of transcutaneous exposures. Occup Med (Lond) 46(4):285-288, https://doi.org/10.1093/occmed/46.4.285.

Sonder GJ, Bovée LP, Coutinho RA, Baayen D, Spaargaren J, van den Hoek A [2005]. Occupational exposure to bloodborne viruses in the Amsterdam police force, 2000-2003. Am J Prev Med 28(2):169-174, https://doi.org/10.1016/j.amepre.2004.10.003. 
Keywords: North American Industry Classification System 922120 (Police Protection), Ohio, Needlestick Injuries, Bloodborne Pathogens, HIV, Hepatitis B, Hepatitis C, Police, Law Enforcement 
This page left intentionally blank 
The Health Hazard Evaluation Program investigates possible health hazards in the workplace under the authority of the Occupational Safety and Health Act of 1970 (29 U.S.C. § 669(a) (6)). The Health Hazard Evaluation Program also provides, upon request, technical assistance to federal, state, and local agencies to investigate occupational health hazards and to prevent occupational disease or injury. Regulations guiding the Program can be found in Title 42, Code of Federal Regulations, Part 85; Requests for Health Hazard Evaluations (42 CFR Part 85).

\section{Disclaimer}

The recommendations in this report are made on the basis of the findings at the workplace evaluated and may not be applicable to other workplaces.

Mention of any company or product in this report does not constitute endorsement by NIOSH.

Citations to Web sites external to NIOSH do not constitute NIOSH endorsement of the sponsoring organizations or their programs or products. NIOSH is not responsible for the content of these Web sites. All Web addresses referenced in this document were accessible as of the publication date.

\section{Acknowledgments}

Desktop Publisher: Shawna Watts

Editor: Ellen Galloway

Evaluation design assistance: Kerton Victory

Statistical analysis assistance: Matthew Groenewold

\section{Availability of Report}

Copies of this report have been sent to the employer and employees at the facility. The state and local health department and the Occupational Safety and Health Administration Regional Office have also received a copy. This report is not copyrighted and may be freely reproduced.

\section{Recommended citation for this report:}

NIOSH [2017]. Needlestick injuries and other exposures to bloodborne pathogens among officers in a city police department. By de Perio MA. Cincinnati, OH:

U.S. Department of Health and Human Services, Centers for Disease Control and Prevention, National Institute for Occupational Safety and Health, Health Hazard Evaluation Report 2016-0121-3284, http://www.cdc.gov/niosh/hhe/reports/pdfs/2016-0121-3284.pdf. 
Delivering on the Nation's promise:

Safety and health at work for all people through research and prevention

To receive NIOSH documents or more information about occupational safety and health topics, please contact NIOSH:

Telephone: 1-800-CDC-INFO (1-800-232-4636)

TTY: 1-888-232-6348

CDC INFO: www.cdc.gov/info

or visit the NIOSH Web site at www.cdc.gov/niosh

For a monthly update on news at $\mathrm{NIOSH}$, subscribe to $\mathrm{NIOSH}$ eNews by visiting www.cdc.gov/niosh/eNews. 